\title{
Triple Phosphate Crystal Measurement
}

National Cancer Institute

\section{Source}

National Cancer Institute. Triple Phosphate Crystal Measurement. NCI Thesaurus. Code C74756.

The determination of the amount of triple phosphate crystals present in a urine sample. 